\title{
7 \\ INDIGENEITY AND MODERNITY IN COLONIAL KARAFUTO
}

For the natives of Otasu (Orok, Gilyak) there are no firewood for homes or logs to build houses, so we've got to ask for help. The Japanese living back of the Shimkuki River cut them down to their stumps, every year two miles long by a mile wide. That's why we've got to ask for help. We want to become Japanese quickly, so please help us. ${ }^{1}$

Some words echo across decades. Fragments of text speak into the imagination; sounds of life rise from the rubble of historical archives. The message translated here was written around 1930 by a villager from the little settlement of Otasu in the Japanese colony of Karafuto (southern Sakhalin). ${ }^{2}$ As its angular sentences suggest, it was written with pain and difficulty in a foreign language (Japanese), for the author of this statement was member of the Nivkh-speaking community, whom the colonial bureaucracy called 'the Gilyak'. Not only were the complicated Japanese characters foreign, the very medium of written messages, addressed to unknown urban officials with unspecified powers over life and death, was alien.

1 Quoted in Tanaka Ryō and D Gendānu, Gendānu: Aru Hoppō Shōsū Minzoku no Dorama (Tokyo: Gendaishi Shuppankai, 1978), p. 61.

2 In this chapter I use the term 'Karafuto' to refer to Japanese-ruled southern Sakhalin, and 'Sakhalin' to refer to the island as a whole. 
Written messages to officialdom were acts of desperation. By the time this letter was written, the forests of Karafuto were falling to make paper for that most literate of all societies, Japan, and the foundations of indigenous life had been uprooted. In 1926 the Uilta-speaking and Nivkh-speaking inhabitants of Karafuto began to be herded into the settlement of Otasu, and in 1930 a 'Native School' was opened, to teach the children of the village Japanese language, literacy, numeracy and loyalty to the emperor. ${ }^{3}$ It was with the help of those schoolchildren that the Nivkh villager composed his halting plea to the colonial authorities.

This chapter explores the landscape of this small corner of the prewar and wartime Japanese colony of Karafuto. The village called Otasu, also sometimes known as 'the Forest of Otasu' (Otasu no Mori) was perched on a sandbank at the confluence of the Poronai and Shisuka Rivers about 70 miles from the Russo-Japanese frontier, and had just one road and a rickety ferry to link it to the outside world. Its houses varied from the substantial homes built by the reindeer-herding entrepreneur Dmitri Vinokurov (discussed further below) and the prominent Uilta shaman Uzlgush and her family ${ }^{4}$ to very basic wooden structures built to a standardised design. Lives flowed out into the grassy spaces between the houses, where dappled dogs wandered among buckets, baskets and racks of drying fish. Beyond the village and the river, the tundra stretched flat to the edges of the sky: in places cleared by logging, but elsewhere still thickly wooded with larch and silver birch. The floor of the forests was cushioned in summer with moss-covered peat. Mosquitoes swarmed in the shadows, and only the reindeer and those who followed them could avoid the bog patches hidden under the tussocky surface.

In September the forests were briefly vivid with autumn colours and the ground covered with cranberries (furep), but in winter the temperature could drop to 30 degrees below zero. Engines seized up in the cold. The fastest travel was by dog or reindeer sled: icy journeys through tunnels of endless translucent whiteness. ${ }^{5}$ Otasu was both short-lived and very small. It existed for just 20 years - roughly from 1926 to 1946, and the

3 Shisuka Dojin Jimusho, Orokko sono ta Dojin no Seikatsu (Shisuka: Yōsawa Chū Shōten, 1935), pp. 30-34.

4 See Nikolai Vishinevskii, Otasu: Etno-Policheshie Ocherki (Yuzhno-Sakhalinsk: Dal'nevostochnoe Knizhnoe Izdatel'stvo, 1994), pp. 133-34.

5 This description is based on Tanaka and Gendānu, Gendānu; Hishinuma Uichi, Karafuto Annai Chimei no Tabi (Tokyo: Chūō Jōhōsha, 1938); and Yamamoto Sukehiro, Karafuto Genshi Minzoku no Seikatsu (Tokyo: Arusu, 1943). 
population at its peak was less than 200. Despite this, a surprisingly large number of records of life in Otasu remain, including official reports, anthropological essays, travel guides, memoirs and photographs.

Otasu was not a 'traditional' indigenous village, but a unique colonial artefact. That fact itself, together with the village's location and history, made it a particularly revealing embodiment of some important facets of colonial policy. Here I want to consider how the design of the village represented the structures and aims of imperial rule, but also the ways in which that design was experienced and reinterpreted both by people who visited Otasu and by the people who lived there. For a village or an urban district can never be seen as a whole, it is always viewed from specific standpoints, even though those standpoints change as the viewer moves on his or her trajectory through the landscape. It is the multiple visions that various individuals had of Otasu, as much as the village's physical design itself, that reveal the complexities of Japanese colonial rule over the indigenous people of Karafuto, and of the indigenous experience and reinterpretation of 'modernity'.

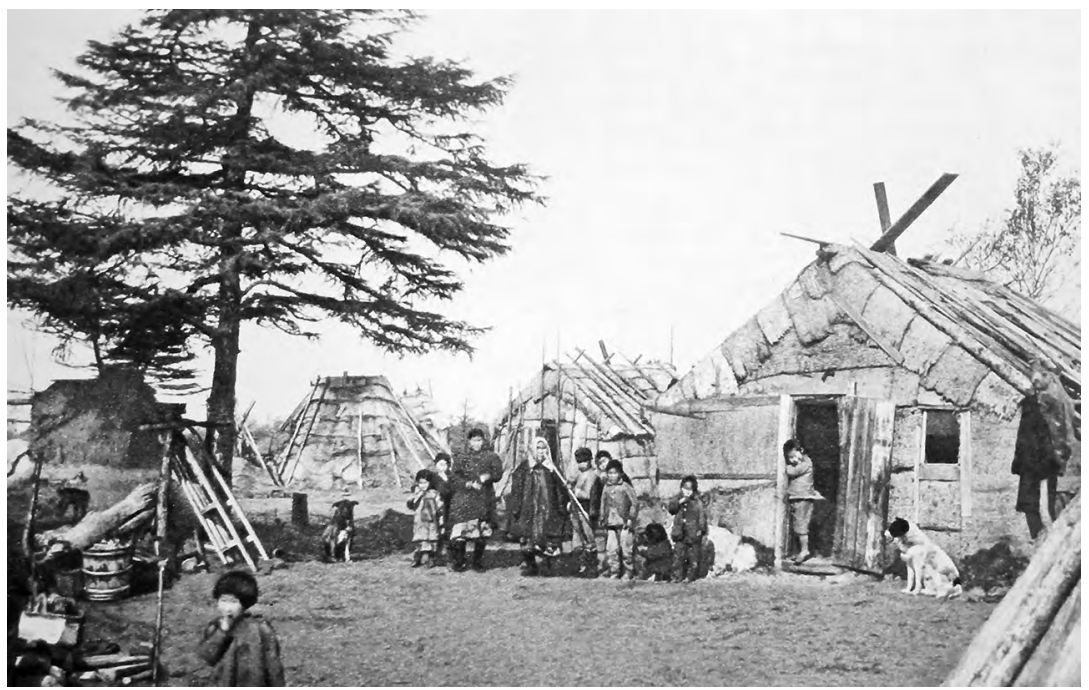

Figure 7.1. Traditional Uilta summer houses on the outskirts of Otasu.

Source: Karafuto Chō, ed., Karafuto Kyōdo Shashinchō (Toyohara: 1934). 


\section{Japan and the Indigenous People of Karafuto}

The extension of Japanese influence over the southern part of Sakhalin had been a long and gradual process, going back to the late seventeenth century. As we saw in the previous chapters, by the middle of the nineteenth century, Japan had extensive fishing interests along the southern coasts of the island, while Russia had also established outposts further north. In the 1855 Treaty of Shimoda, Russia and Japan reached an agreement under which the island would be treated as the joint territory of both countries, but this proved impractical, and there were recurrent conflicts between Japanese and Russian settlers. Under the 1875 Treaty of St Petersburg, Japan agreed to transfer control of the island to Russia in return for Japanese sovereignty over the entire Kurile Island chain to the east. However, as part of the spoils of the Russo-Japanese War of 1904-05, Japan regained control of the southern half of Karafuto, as far north as the 50th parallel; and, during the period from 1921 to 1926, during its intervention in Siberia following the Russian Revolution, Japan also briefly occupied the northern half. ${ }^{6}$

All of these events had a massive impact on the lives of the indigenous people of Karafuto/Sakhalin. Figures for the last decade of the nineteenth century suggest that, at that time, the island had around 4,000 indigenous inhabitants, of whom the largest group were Nivkh (generally referred to by prewar officials and anthropologists as 'Gilyak'), who also inhabit parts of the eastern coastline of continental Siberia. ${ }^{7}$ While most of the 2,000 or so Nivkh lived in the north of the island, most of the Ainu population of Karafuto was concentrated in the south. Before 1875, the number of Karafuto Ainu had also been estimated at around 2,000. But many Karafuto Ainu worked in Japanese fisheries and had close links to Hokkaido. At the time of the Treaty of St Petersburg, those who remained on Karafuto automatically became Russian citizens. Escaping this shift in nationalities, over 800 Karafuto Ainu chose or were persuaded move to Japan, where many had close links to Hokkaido Ainu communities or

6 Taisho Nakayama, 'Japanese Society on Karafuto', in Voices from the Shifting Russo-Japanese Border: Karafuto/Sakhalin, ed. Svetlana Paichadze and Philip A Seaton (London and New York: Routledge, 2015), pp. 19-41, reference from pp. 20-21, doi.org/10.4324/9781315752686.

7 See James Forsyth, A History of the Peoples of Siberia (Cambridge: Cambridge University Press, 1992), p. 219. 
to Japanese fishing enterprises. Despite their wish to live in the north of Hokkaido, close to Karafuto, they were then forcibly transferred en masse to the village of Tsuishikari, near Sapporo, and where many succumbed to epidemic diseases. ${ }^{8}$ The other main indigenous group on the island were the reindeer-herding Uilta (referred to by the colonial rulers as 'Orok'), who probably numbered around 700-800 at the end of the nineteenth century, and who lived in the centre of the island - the area that came to be bisected by the border between the Japanese colony of Karafuto and Soviet Sakhalin. Meanwhile, other reindeer-herding people from the Evenk and Saha (Yakut) language groups were also moving in small numbers into Sakhalin from the Siberian mainland, while small groups of Ul'chi people from the Siberian mainland also travelled to Sakhalin to trade, and sometimes settled there. ${ }^{9}$

Sakhalin thus became the focus of complex interactions between multiple cultural and linguistic groups. Intermarriage between indigenous groups was common, ${ }^{10}$ and the Russian ethnographer Bronislaw Piłsudski, who conducted careful surveys of Sakhalin Ainu communities in the first decade of the twentieth century, noted that Ainu on the west coast of the island also sometimes married Chinese or Koreans who crossed from the continent to collect kelp. ${ }^{11}$ Piłsudski estimated that about 10 per cent of the Ainu population of Sakhalin had non-indigenous (Japanese, Russian, Korean or Manchurian) ancestry, and also recorded numerous instances of intermarriage between Uilta women and Nivkh, Evenk and others. ${ }^{12}$ Newly arriving groups like Evenk and Saha also had an important impact on the lives of older-established indigenous groups. Evenk influence seems to have been a major factor in the nominal conversion of many Uilta to Russian Orthodox Christianity, ${ }^{13}$ and also helped to strengthen

8 Karafuto Ainu Shi Kenkyūkai, ed., Tsuishikari no Ishibumi (Sapporo: Hokkaidō Shuppan Kikaku Sentā, 1992); Kōichi Inoue, 'A Case Study on Identity Issues with Regard to Enchiws (Sakhalin Ainu): Reconsidering B. Pilsudski's "Draft Rules for the Establishment of Authority over the Sakhalin Ainu" (1905)', Hoppō Jinbun Kenkyū 9 (2016): pp. 75-87.

9 AV Smolyak, Etnicheskie Protsessy u Narodov Nizhnevo Amura i Sakhalina (Moscow: Nauka, 1975).

10 See, for example, Bronislaw Piłsudski, 'B. O. Pilsudski's Report on his Expedition to the Ainu and Oroks of the Island of Sakhalin in the Years 1903 to 1905', in The Collected Works of Bronislaw Pitsudski, vol. 1, The Aborigines of Sakhalin, ed. Alfred F Majewicz, Trends in Linguistics Documentation 15-1 (Berlin and New York: Mouton de Gruyter, 1998), pp. 192-221, doi.org/ 10.1515/9783110820768-013.

11 Piłsudski, 'B. O. Pilsudski’s Report', p. 194

12 Piłsudski, 'B. O. Pilsudski's Report', p. 211; Bronislaw Piłsudski, 'From the Report on the Expedition to the Orok in 1904', in The Collected Works of Bronislaw Pitsudski, pp. 618-77, reference from p. 634, doi.org/10.1515/9783110820768-028.

13 Piłsudski, 'B. O. Pilsudski’s Report', p. 207. 
the Uilta reindeer-herding economy, though Evenk and Saha also seem to have used their greater wealth and connections to the continent to enter into exploitative trade relations with local Uilta and Nivkh. At least until the early twentieth century, Nivkh and Uilta from Sakhalin continued to travel regularly to the continent to trade goods at posts on the Amur River (as they had done in earlier times - see Chapter 5). A Uilta informant told British traveller Charles Henry Hawes in 1901 that wealthier members of his community in particular travelled to Nikolaevsk on the Amur to sell 'furs, reindeer etc. and bring back large quantities of rice, tea, tobacco'. ${ }^{14}$

For the people who lived in central Sakhalin, the division of their homeland between two increasingly hostile powers had a devastating effect. Unlike the borders of earlier empires, the frontier across the island did not meander along rivers or the crests of mountain ranges, but ran in a straight line along the 50th parallel: a course made possible by nineteenth-century improvements in the techniques of surveying. During the first years of its existence the frontier remained largely invisible at ground level, its presence signalled only by occasional wooden boundary-markers. The indigenous Nivkh and Uilta people, and the handful of Russian and Japanese settlers who lived near the border, continued to travel relatively freely to and fro though the swampy forest, which stretched unbroken across the limits of empire. When he visited the region in 1912, the Japanese ethnographer Torii Ryūzō was still able to cross the frontier unchallenged with the help of local guides, and was welcomed with gifts of tobacco and potatoes by a family living in an isolated outpost on the Russian side. ${ }^{15}$

But after the Russian Revolution, and even more as tensions between Russia and Japan intensified during the 1930s, the frontier acquired a physical presence that cut through the everyday lives of the region's inhabitants. Wooden boundary-posts were replaced by concrete blocks; a cleared space, like a wide straight road, was gouged out of the forest, and those who crossed it risked being shot or imprisoned for spying. So the trade route that had for centuries linked Hokkaido to the Amur region via Sakhalin was severed, just as the eastern trade route linking Hokkaido to Kamchatka via the Kurile Islands was also cut. Relatives, trading partners and former neighbours on either side of the border were involuntarily and irrevocably separated from one another. The practical consequences were

14 Charles Henry Hawes, The Diaries of Charles Henry Hawes, Book VII, transcript, MS. Eng. misc. b. 443, Bodleian Library, p. 109.

15 Torii Ryūzō, Aru Rōgakuto no Shuki, reprinted in Torii Ryūzō Zenshū, vol. 12 (Tokyo: Asahi Shinbunsha, 1976). 
profound. There were, for example, more men than women in the small Uilta population of Japanese Karafuto, but the border made it increasingly difficult for the them to seek Uilta brides from Russian Sakhalin. ${ }^{16}$ People who shared a common history, in some cases even members of the same family, found themselves incorporated into the modern state as subjects of two very different and generally hostile great powers: on the one side, the Japanese empire, on the other, the Tsarist Russian empire and its successor, the Soviet Union.

Most of surviving Ainu who had left the island in the 1870s went back to their homeland: some of them while it was still under Russian rule, and the remainder after Japan regained control of southern Karafuto/Sakhalin in $1905 .{ }^{17}$ These Ainu had acquired Japanese family registrations, and were thus treated in legal terms as 'Japanese'; all other 'Karafuto Natives' had no family registers, but were enrolled in a 'Native List' (dojin meibo). This meant that they were not covered by the provisions of Japanese criminal and civil law, which made it virtually impossible for them to acquire property or run their own businesses. In 1932, after a prolonged campaign by Karafuto Ainu, the colonial government finally extended full Japanese citizenship to all of them, but not to the small group of other indigenous people, who in the 1930s numbered in total between 400 and 500 , with the largest group being the community of around 300 Uilta. ${ }^{18}$

\section{Resettlement, Farming and the Architecture of Modernity in Japanese Karafuto}

A survey carried out in the first years of colonisation found Ainu living in 43 settlements, some of them with populations of less than 20 people. ${ }^{19}$ From 1907 onwards, however, the Karafuto authorities amalgamated this scattered population into just nine villages: five on the east coast and four on the west coast. ${ }^{20}$ Concentrated settlements were not only easier to

16 Nakanome Akira, Karafuto no Hanashi (Tokyo: Sanseidō, 1917), p. 37.

17 Inoue, 'Case Study on Identity Issues'.

18 Shisuka Dojin Jimusho, Orokko sono ta, p. 1.

19 Kasai Takechiyo, Karafuto Dojin Kenkyü Shiryō (Mimeographed report, 1927), pp. 97-98 and $120-21$.

20 Karafuto Chō, ed., Karafuto Chō shisei sanjūnen shi, vol. 2 (Tokyo: Hara Shobō, 1973), p. 1984. Original published in 1936. 
control and to fit into the norms of Japanese local government, they also provided the basis for other modernisation and assimilation measures: the building of schools, shops, roads and police stations.

One result of this resettlement was the creation of a sharper division between Ainu and other indigenous groups in the colony. Early colonial surveys had commented on the close contacts and frequency of intermarriage between different peoples, and nineteenth-century accounts suggest that a number of hamlets on the central parts of the Sakhalin coast had mixed populations of Ainu, Uilta and Nivkh; but the drawing of the frontier and the resettlement of populations made such interactions increasingly difficult. The forced movements of Karafuto Ainu population in some cases aroused bitter protests. One important cause of distress was the fact that relocation removed people from the places where their relatives and ancestors were buried. ${ }^{21}$ The resettlement policy did, however, provide the colonial authorities with an opportunity to superimpose their vision of civilisation and order on indigenous life.

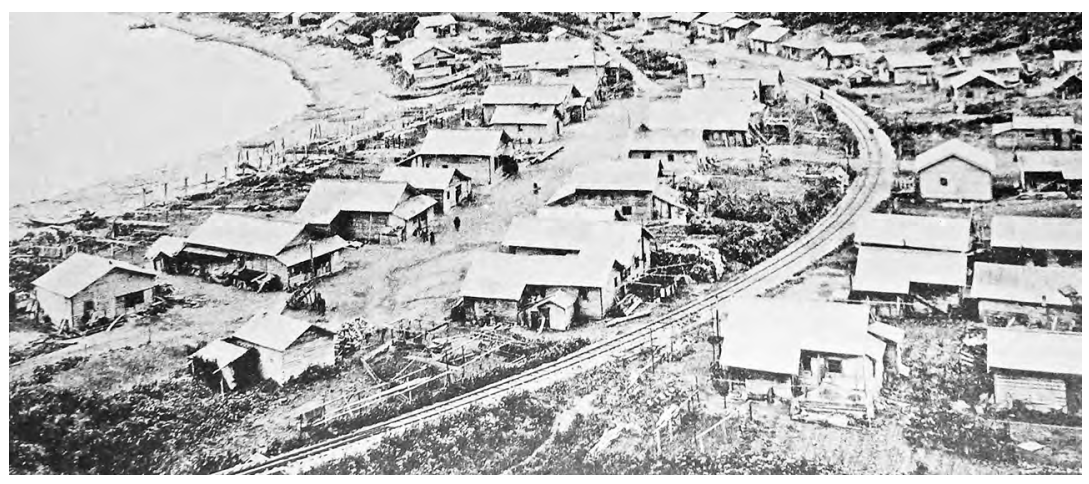

Figure 7.2. The Ainu 'model' village of Torandomari.

Source: Karafuto Chō, ed., Karafuto Shashinchō (Toyohara: 1929).

The new Ainu villages of Karafuto embodied a vision of modernity that, interestingly enough, closely resembled that of indigenous villages that were to be constructed at the same time across the border in Soviet Sakhalin, where the Nivkh population was gathered into villages of standardised two- or three-bedroom houses built according to a 'model plan'. ${ }^{22}$ The new Ainu settlements in Japanese Karafuto were typically

21 Kasai, Karafuto Dojin Kenkyū Shiryō, p. 101.

22 See, for example, Chuner M Taksami, Nivkhi: Sovremenoe Khozyastvo, Kul'tura i Byt (Leningrad: Nauka, 1967), pp. 165-66. 
constructed along a main road, with a row of identical houses on either side. The houses themselves were designed along the lines of Japanese urban housing, though little thought seems to have been given to anything other than providing basic shelter. It was left to the inhabitants themselves to give their standardised homes character and life. Shirakawa Shinsaku, who grew up in the Ainu village of Shirahama on the southeast coast of Karafuto in the 1930s, recalls that his home was one of a row of identical rectangular buildings with two six-mat rooms at the front and two six-mat rooms at the back. The houses had no cupboards for clothes or bedding, nor any inside toilets:

Depending on the families, some people put in sliding doors and screens. It was the same with cupboards. Better-off families got their own proper furnishings, including cupboards, but poorer families had absolutely nothing in their houses. They were just totally empty. There was no money so they couldn't buy things, you see. But people who were good with their hands made things by themselves and so on. In our house, my elder sister bought and installed a thick paper sliding door herself. ${ }^{23}$

\section{Otasu: Showplace of the Ethnicities}

Yet, both south and north of the border that divided the island of Karafuto/ Sakhalin, policies of assimilating and 'modernising' indigenous people, paradoxically, went hand in hand with an urge to preserve and display aspects of the 'exotic' culture of the empire's far-flung and ethnically diverse subjects. In Japanese Karafuto, the place that most symbolically embodied this paradox of empire was the settlement Otasu. During the first years of the colony's existence, the colonial government of Karafuto had paid little attention to the non-Ainu indigenous groups, who lived in relatively remote areas near the Russian border, though in 1912-13 it commissioned a survey of these groups by education expert Nakanome Akira, whose report, published in 1918, proposed an intense program of assimilation. ${ }^{24}$ Little was done to follow up on these suggestions until

23 Shirakawa Shinsaku and Shirakawa Yaeko, with Fujimura Hisakazu, 'Shirahama Chihō no Kurashi', in Henke to Ahachi, ed. Fujimura Hisakazu and Wakatsuki Jun (Sapporo: Sapporo Terebi Kabushiki Kaisha, 1994), pp. 147-48.

24 Nakanome Akira, Dojin Kyōka Ron (Tokyo: Iwanami Shoten, 1918); see also Aoyanagi Fumiyoshi, 'Otasu no "Seiritsu" to Kyōikusho', Aldo 19 (2002): pp. 6-11, reference from p. 6. 
the 1920s, but in 1923 a group of 18 Uilta and Nivkh were dispatched on a tour of the colonial capital Toyohara, which was intended to provide them with an introduction to the superior civilisation of the colonisers. ${ }^{25}$

From 1926 onward, assimilationism began in earnest, and the non-Ainu indigenous people of the colony began to be relocated into this single centralised settlement. Described colonial officials as 'the capital city of the natives' (dojin no miyako) and as a 'representative native village' (dojin no daibyo buraku), by 1938 Otasu had a population that was carefully enumerated and ethnically labelled as follows: 87 'Gilyak' (i.e. Nivkh) living in 16 houses; 78 'Orokko' (i.e. Uilta) living in 14 houses; two households of eight people who were a mixture of 'Gilyak' and 'Sandä' (i.e. Ul'chi); and one Yakut (i.e. Saha) household whose 10 members included two 'Yakuts', five 'Tungus' (i.e. Evenk), one 'Orokko' and two Japanese. ${ }^{26}$ Although the official report fails to mention this, there were also other Japanese residents in the village: a couple named Kawashima Hideya and Nao, who jointly ran the local school, and their small children.

On the one hand, Otasu was a focus of modernisation policies that closely resembled those applied to the Ainu population of Karafuto. Nakanome Akira had proposed that assimilationary education was needed to turn the indigenous people of Karafuto into 'people of economic worth to the nation'. ${ }^{27}$ The Otasu 'Native School' (dojin kyoikusho), opened in 1930 , proclaimed its mission as being to 'foster sentiments of nationality (kokuminteki jōsō)', 'impart vocational training', 'nurture a spirit of cooperation', and 'develop a spirit of diligent labour'. ${ }^{28}$ Lessons (all of which were conducted in Japanese) emphasised stories from Shinto mythology and the heroic moments of Japanese history, and the school received several visits from army officers who gave glowing accounts of Japanese military victories in Japan's expanding war with China. ${ }^{29}$ The colonial authorities in the neighbouring town of Shisuka also approvingly noted the gradual shift of Uilta people from their traditional bark-roofed huts and tents to wooden houses, which seem to have been much like the houses built in the Ainu village of Shirahama and elsewhere. ${ }^{30}$

25 Aoyanagi, 'Otasu no "Seiritsu”, p. 6.

26 Shisuka Dojin Jimusho, Orokko sono ta, pp. 1 and 28.

27 Nakanome, Dojin Kyōka Ron, p. 108.

28 Shisuka Dojin Jimusho, Orokko sono ta, p. 31.

29 Vishinevskii, Otasu, pp. 126-27.

30 Shisuka Dojin Jimusho, Orokko sono ta, p. 28. 


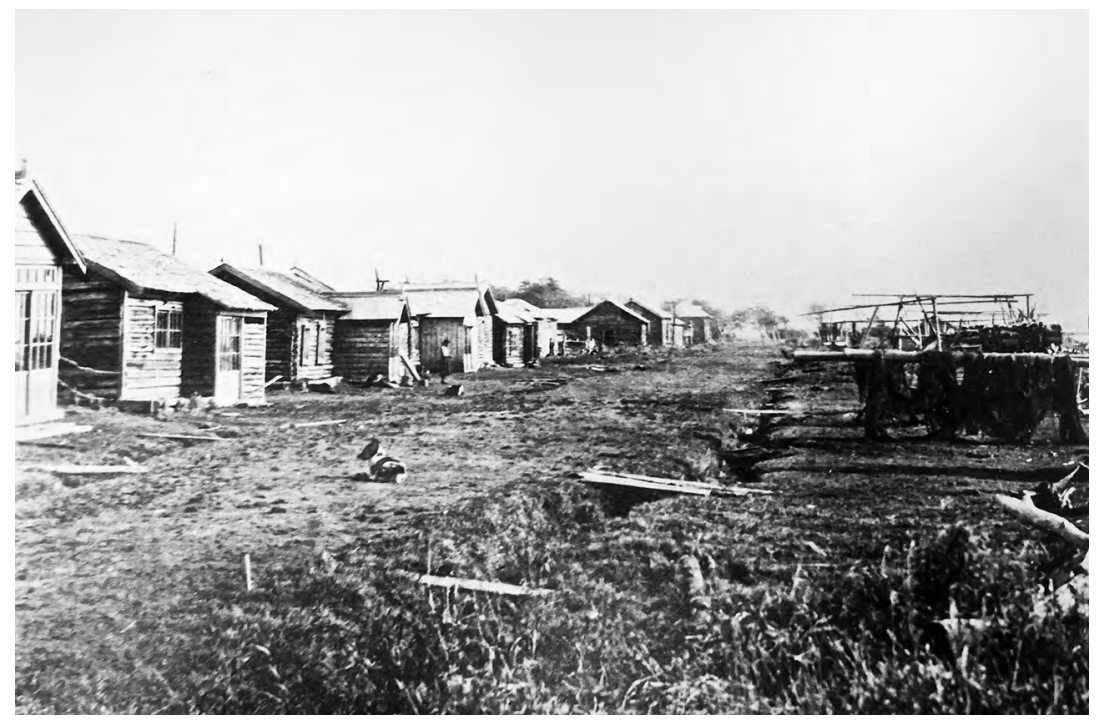

Figure 7.3. Colonial modern housing in Otasu.

Source: Karafuto Chō, ed., Karafuto Shashinchō (Toyohara: 1929).

At the same time, though, the village was presented to the outside world as a small model of the Japanese empire's rule over ever-expanding realms of exotic peoples. While the colonial government generally discouraged tourist visits to Ainu villages, Otasu was promoted as a highlight of the colonial Karafuto tourist experience, where guidebooks promised visitors the opportunity to see the indigenous people of the colony living 'a life which was close to its primitive state' (genshi no chikai mama no seikatsu). ${ }^{31}$ The appeal of this promise was so great that by the late $1930 \mathrm{~s}$ the village was said to be 'extremely busy with visitors (from Japan) in midsummer'. ${ }^{32}$ Since, by this time, around 30 per cent of the colony's Uilta population and 75 per cent of its Nivkh population were living in Otasu (and the percentages were steadily rising), the village also became a focus for Japanese anthropological fieldwork on the indigenous peoples of Karafuto.

This presentation of the village as a symbol of Japan's rule over the exotic other was perfectly encapsulated in an exhibition of life in Karafuto, staged in Tokyo in 1940 as part of the national celebration of the '2,600th anniversary of the mythical creation of the Japanese imperial line.

31 Hishinuma, Karafuto Annai Chimei, p. 77.

32 Shisuka Dojin Jimusho, Orokko sono ta, p. 28. 
The exhibition included a life-sized panorama of the village of Otasu, where visitors could see waxwork models of the settlement's Nivkh and Uilta people engaged in traditional fishing and herding activities. The only tangible representation of the assimilation policies the authorities were so vigorously pursuing in the village was the background music, which featured a recording of the village children singing Japanese patriotic songs. ${ }^{33}$ As a new 'native village' almost entirely designed by the colonising power, Otasu thus became a particularly vivid physical representation of the aims and contradictions of policies towards indigenous people, and of the indigenous people's response to the those policies.

\section{The House of the 'Village Chief'}

In the centre of the settlement, close to a landing point on the river, stood the key symbols of colonial rule - the school, a public bath house and a martial arts hall $\left(d_{\bar{o}} \bar{j} \bar{c}\right)$ and behind them, on a slight rise in the sand dunes, the Shinto shrine. On either side of the central space occupied by these symbols of power were rows of houses, neatly divided by ethnicity - the Nivkh houses to east along a tributary of the Poronai River and the Uilta houses to the west along the Shisuka River. A ferry linked the settlement to the nearby town of Shisuka, and thus to the outside world, and from the pier where the ferry tied up, a tourist route took visitors in a loop around the village.

The first stop on this route was one of the village's largest buildings, the home of the 'village chief' Dmitri Vinokurov, which stood to the west of the village near the Nivkh side of the settlement. Here Vinokurov and his Evenk wife Anastasia offered visitors Russian coffee, and tourists were given a chance to photograph each other amongst the large herd reindeer that grazed peacefully in the woodland behind the chief's house. They were also treated to lectures on the ideology of Greater East Asia by Vinokurov, who told one group of visitors in the late 1930s that:

originally the great land of northern Asia belonged to the gods of nature, and I believe it is therefore natural for them to seek salvation and protection from the power of Japan's rising sun flag. However, the great army of the Red Flag is seeking to spread over the great northern land, and all Asia is in crisis. ${ }^{34}$

33 'Hokumon no mamori Karafuto tenrankai', Karafuto jihō 33 (1940): pp. 69-77.

34 Hishinuma, Karafuto Annai, pp. 78-79. 
'Behind the Red Flag', he added darkly, 'stands Roosevelt'. ${ }^{35}$ Vinokurov employed his own interpreter, a Japanese man named Umemiya Tomisaburō, who was (like Vinokurov) married to a Evenk woman, Ulyana, ${ }^{36}$ and it seems that much of the explanation of local customs tourists received came from Umemiya and his family. ${ }^{37}$

Vinokurov's physical location at the entrance to the village, and his title of 'village chief', are particularly interesting because none of the other Otasu villagers regarded him as a 'chief'. Indeed, he seems to have been regarded with considerable suspicion by his neighbours, and to have had a supercilious attitude to the other indigenous people of the village. ${ }^{38}$ Vinokurov was in fact an immigrant from Siberia - a relatively prosperous member of the Saha (Yakut) indigenous people of Siberia. He had been born in 1884 in the settlement of Yarmonka on the banks of the Suola River in the Yakut region of Siberia, and worked as a guide for oil prospectors before moving to Sakhalin in 1910 in the hope of making money on the periphery of the newly emerging oil business there. ${ }^{39} \mathrm{He}$ was a shrewd merchant and entrepreneur and had amassed considerable wealth by the time the Japanese occupation of northern Sakhalin began. Vinokurov first came into contact with the Japanese authorities during the period from 1921 to 1926 when Japan, as part of its so-called Siberian Expedition following the Russian Revolution, occupied the northern half of Sakhalin. In 1921, the Japanese ethnographer Torii Ryūzō travelled to the Tym River, which had long been a meeting place for the indigenous communities from various parts of Sakhalin and Lower Amur. There he encountered Vinokurov with a group of other Saha from the mainland engaged in building a road along the banks of the river. ${ }^{40}$

During the occupation, the Japanese military attempted to organise and distribute propaganda to the indigenous people of northern Sakhalin, in the hope of turning them into an advance guard for resistance to a return of Soviet forces to the region. In this, they appear to have had

\footnotetext{
35 Hishinuma, Karafuto Annai, p. 79.

36 See Vishinevskii, Otasu, p. 39.

37 See Hishinuma, Karafuto Annai, p. 80.

38 Minzoku Saigo no Hitobito: Otasu no Dojin (Shisuka: Karafuto Insatsusha, 1937), p. 9; see also Hokkaidō Dōritsu Hoppō Minzoku Hakubutsukan, 'Tenji Kaisetsu: Karafuto 1905-45 - Nihonryō jidai no shōsū minzoku', in Karafuto 1905-45 - Nihonryō jidai no shōsū minzoku, ed. Hokkaidō Dōritsu Hoppō Minzoku Hakubutsukan (Abashiri: Hokkaidō Dōritsu Hoppō Minzoku Hakubutsukan, 1997), pp. 5-14, reference from p. 11

39 Vishinevskii, Otasu, p. 7.

40 Torii, Aru Rōgakuto, pp. 294-300.
} 
little success. Vinokurov, however, did enthusiastically embrace the Japanese cause, apparently hoping that Japanese support would help him establish an independent Yakut Republic in his homeland. He was appointed a community leader, and began to cultivate powerful friends within Japanese military and political circles. ${ }^{41}$ When Japan withdrew from the northern half of the island in 1925, Vinokurov moved to an area close to the dividing line between the Soviet and Japanese sectors, where he herded reindeer and continued his trading activities, but in 1926, while on a hunting trip on the northern side of the still porous border, he was arrested by the Soviet security forces on a charge of collaborating with the Japanese, and released only when he promised to gather intelligence on Japanese Karafuto for the Soviet Union. He then fled south to the town of Shisuka, and soon after was installed as 'chief' of the native village of Otasu.

Throughout the late 1920s and much of the 1930s, Vinokurov was encouraged in his dream of creating a Yakut Republic by Japanese politicians and activists, among them the well-known nationalist thinker Toyama Mitsuru (1855-1944). He visited Tokyo three times for negotiations on the subject, as well as writing a lengthy article for a Japanese colonial newspaper setting out his vision for the liberation of Eastern Siberia by the Japanese empire. ${ }^{42}$ With support from the Japanese colonial authorities, he also helped to create an experimental station to develop more scientific methods of reindeer breeding and raising. Meanwhile, the Japanese colonial authorities seem deliberately to have created the 'native capital' around him, using him as a focus for an imperial vision of Japan's relationship with the indigenous peoples of the North. Because the reindeer herders who worked for Vinokurov could easily cross the border undetected, and because Vinokurov maintained communication with people in Northern Sakhalin and Siberia, the Japanese government (like the Soviet administration to the north) clearly saw him as a valuable source of intelligence.

41 Vishinevskii, Otasu, pp. 7-10 and 21-25.

42 Minzoku Saigo no Hitobito, p. 10; see also Vishinevskii Otasu. 


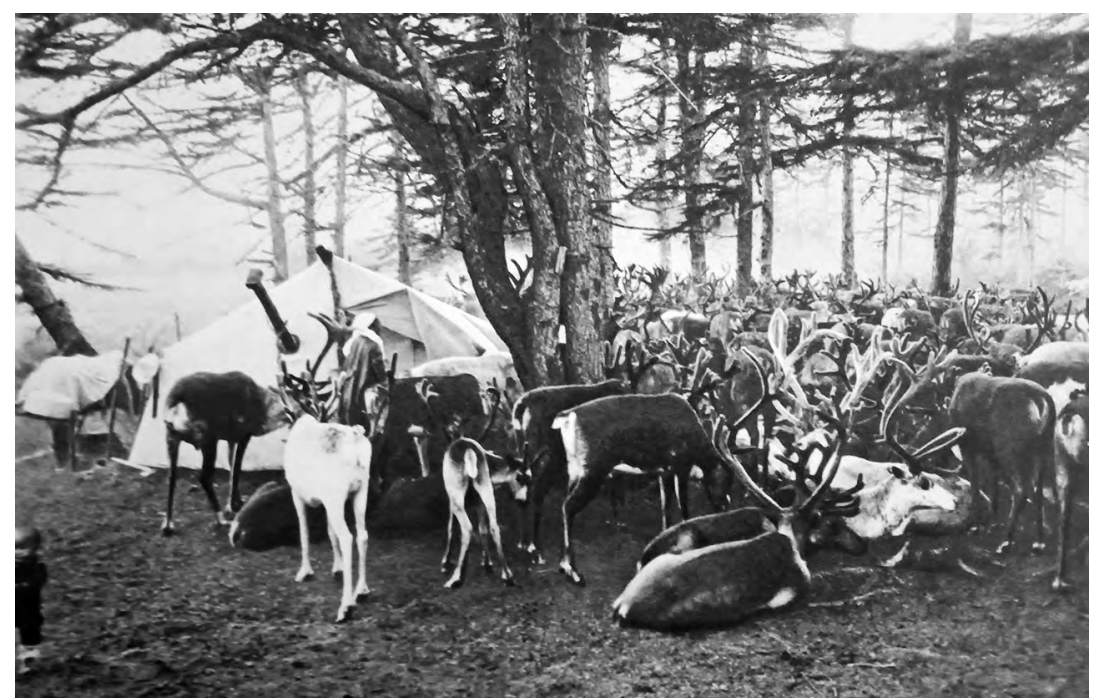

Figure 7.4. A reindeer herd near Otasu.

Source: Karafuto Chō, ed., Karafuto Kyōdo Shashinchō (Toyohara: 1934).

\section{The Reindeer Herders' Tents}

After visiting Vinokurov, tourists continued on their path around the village, generally focusing their eyes and their camera lenses not on the modern 'barrack-style housing' in which most of the Nivkh and Uilta population of Otasu lived nor on the agricultural projects in which they were required to participate, but rather on the visual signs of 'tradition', such as the distinctive Nivkh and Uilta graves that lay scattered in the forest near the village. Their photographs often picked out the bark-roofed houses where some Uilta families still lived in summer, and the conical tents they inhabited when they followed the reindeer in winter. Tourists also visited the school to buy examples of the beautiful neo-traditional embroidery made by the village girls in the handicraft lessons. ${ }^{43}$

Anthropologists and linguists spent longer in the village and interacted more intensively with its inhabitants. Yet, viewing Otasu through the prism of the anthropological quest for pristine culture, their descriptions of local society too have a remarkable capacity to foreground some details

43 Hishinuma, Karafuto Annai, p. 79; see also Kitagawa Aiko, “'Otasu” no kurashi to watashi', in Hokkaidō Dōritsu Hoppō Minzoku Hakubutsukan, Karafuto 1905-45, p. 15. 
while blotting out others altogether. A striking example is ethnographer Yamamoto Sukehiro's account of the Life of the Primitive People of Karafuto [Karafuto Genshi Minzoku no Seikatsu], published in 1943. Yamamoto was the director of the museum built by the colonial authorities in the Karafuto capital of Toyohara, and his fieldwork was conducted in and around Otasu, yet his study almost entirely erases the signs of colonial modernity. The photographs that fill his small but richly illustrated book show dog sleds racing across the frozen tundra, reindeer herders in their birch-bark houses or winter tents, and indigenous men and women engaged in traditional handicrafts. ${ }^{44}$

Yamamoto's ethnographic vision of Otasu is encapsulated in his discussion of the 'Yakut' (Saha) people of Karafuto. The sample he had to work with here was small, since there were only two Saha families in Japanese Karafuto: the Vinokurovs and the family of a man named Ivan Petrovich, who was employed by Vinokurov to look after his reindeer herds. Yamamoto only briefly mentions Vinokurov, whom he describes as a 'ruling class Yakut'. ${ }^{45}$ The Otasu 'village chief', who read Russian newspapers and drank Russian coffee, and whose daughter collected French dolls, did not readily fit into Yamamoto's ethnographic framework. His description of the life of Karafuto's Yakuts is therefore a rhapsodic account of Ivan Petrovich's timeless existence in the Karafuto tundra as he follows the reindeer, sleeping in a tent and living life in tune with the rhythms of nature. There is no hint in any of this that the Petrovich family was in fact part of Vinokurov's extended household, and presumably spent a fair amount of their existence in Vinokurov's Russian-style house, being regularly treated to their employer's extended monologues on Pan-Asianism, Marxism and FD Roosevelt.

The same extraction of the 'indigenous' from the 'modern' recurs throughout Yamamoto's accounts of Otasu's indigenous people. It continues, too, in the numerous ethnographic works he published in the postwar period on the basis of his 1930s and 1940s fieldwork, as it does in the work of other prominent ethnographers like Ishida Eiichirō, who also performed fieldwork in prewar Otasu. ${ }^{46} \mathrm{~A}$ common theme of

44 Yamamoto, Karafuto Genshi Minzoku.

45 Yamamoto, Karafuto Genshi Minzoku, p. 12.

46 See, for example, Ishida Eiichrō, 'Hōryō Minami Karafuto Orokko no Shizoku ni tsuite - 1', in Ishida Eiichirō Zenshū, vol. 5 (Tokyo: Chikuma Shobō, 1970), pp. 333-75. 
these ethnographic works is a lament that the pristine traditional lifestyle is on the brink of disappearing, and yet it is constantly re-created in the minds of the ethnographers as a kind of essence extracted from the more messy realities they encountered on their visits to the field.

\section{Farm Fields and School Classrooms}

In these ethnographic accounts, therefore, we receive no glimpse of the other Otasu that emerges forcefully from the writings of visitors like Kasai Kōmuru. Kasai, visiting the village in 1941, saw only the transformations wrought by the modernising hand of Japanese colonialism. He depicts the past of the indigenous inhabitants as one of degradation and 'defeat', in which they had become spectacles for the entertainment of others. Now, thanks to the impact of assimilation and development policies, he writes, the Uilta and Nivkh have shifted from their hunting and herding existence and begun to cultivate fields and eat vegetables; the young speak Japanese, and the doors of houses are adorned with name plates showing both indigenous names and the new Japanese names villagers had been encouraged to adopt. 'The wind of a new century', proclaims Kasai, 'is sweeping through the lives' of the indigenous people of Otasu. The men of the village, he observed, were almost all absent during his visit, having gone off to undertake paid work at construction sites, farms or fisheries, etc.; and (as Kasai noted with amazement) even the young man working in the engine room of the steam ferry that plied the route across the Poronai River between Otasu and Shisuka could be identified by his 'dull and expressionless face' as a member of the indigenous community: 'When I noticed this I was astonished - they're even working in places like this!' ${ }^{47}$ The subject of the condescending comment was a young Uilta man named Daaxinneeni Geeldanu (discussed further below), who would later recall how the tourists on the boat would often ask him weird questions about 'natives' and recount wildly inaccurate stories about strange 'Orok' customs, as though they regarded the indigenous people as 'some kind of monsters. ${ }^{48}$

47 Kasai Kōmuru, 'Otasu no Dojintachi', Karafuto 13, no. 10 (1941): pp. 104-07, reference from p. 104.

48 Tanaka and Gendānu, Gendānu, p. 65. 
In these various 'readings' of the landscape of Otasu, then, we can see how different observers adopted contrasting viewpoints that made one aspect of the village's ambivalent symbolism visible, and another invisible. Observers like Kasai saw little but the modern housing, the newly created farm fields (which were largely unsuited to the Otasu environment, and were repeatedly washed away by floods) and the school with its Japanesespeaking pupils who would soon be 'taking their place in the workplaces of life just like Japanese people'. ${ }^{49}$ Tourists and many anthropologists, meanwhile, chose paths through this landscape that concealed the school, the farm fields and the modern housing, and revealed vistas of fur-clad hunters, grazing reindeer herds and tent-dwelling indigenous people.

The underlying assumption that framed both these fields of vision was that it was possible to be indigenous and traditional, or to be modernising and 'on the way to becoming' Japanese, but it was not possible to be both at once. From this perspective, the category of 'Japaneseness' could contain both a 'traditional' and a 'modern' aspect - the indigenous people of Otasu, for example, could in some circumstances be 'patriotic Japanese' while also herding reindeer - but the category 'indigenous' could only equate to 'traditional': they could not simultaneously be 'Uilta' or 'Nivkh' and 'modern'. There was no space within this vision for a recognition that indigenous culture was itself dynamic, rapidly adapting to circumstances by the absorption and creative use of outside influences: no space, for example, for discussing how the tents used by the reindeer herder Ivan Petrovich were in fact Russian military tents adapted to Saha needs.

A few Japanese observers of Otasu, however, did manage to view the village from a somewhat more complex perspective. One of these observers was the schoolteacher, Kawamura Hideya, who spent some 15 years in Otasu, living in quarters attached to the schoolhouse in the middle of the village. Kawamura seems to have been genuinely liked and respected by many of his pupils, and he left some careful and sympathetic accounts of the indigenous society of Otasu. In these, Kawamura acknowledged, not only that indigenous society was rapidly changing in response to Japanese colonialism, but also that this was just part of a long history of cultural interaction and change that had produced the forms of 'tradition' so eagerly sought out by tourists to Otasu. He described, for example, the variety of clothing worn by the people of Otasu, which for men varied

49 Kasai, 'Otasu no Dojintachi', p. 104. 
from embroidered outfits worn with fur boots to suits and neckties, and for women were often plain blouses with skirts and jackets. 'Tourists to Otasu', Kawamura noted,

sometimes see the women's clothes and say 'Hey, the natives are wearing western clothes!' However, this sort of hasty conclusion is problematic. Their undershirts are called uribaf or uribaashika [in the Uilta language], and this is derived from the Russian rybashka [shirt], because they are like the undershirts worn by Russian peasant women. ${ }^{50}$

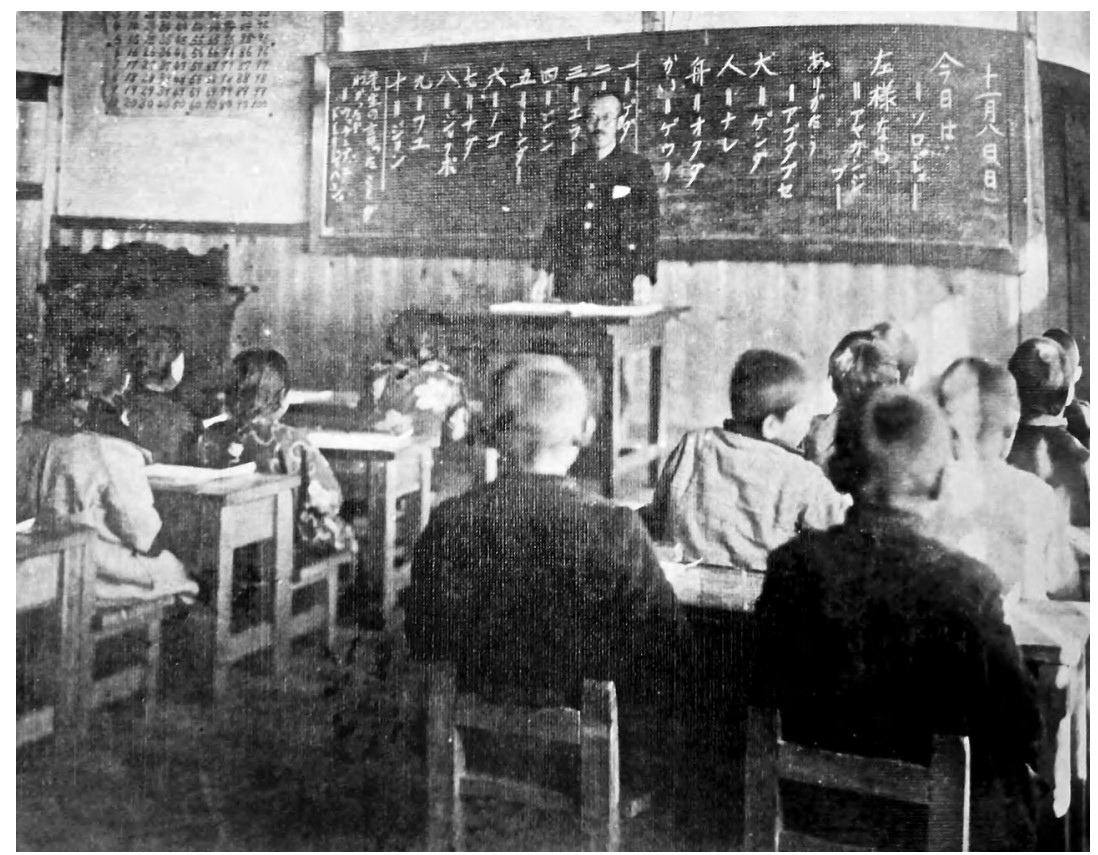

Figure 7.5. Kawamura Hideya teaching a class at the 'native school', Otasu.

Source: Karafuto Chō, ed., Karafuto Kyōdo Shashinchō (Toyohara: 1934).

He himself was indeed actively promoting this type of creative hybridisation by (for example) encouraging his female pupils to apply traditions of Uilta and Nivkh embroidery to the production of artefacts like purses and table mats for sale to visiting tourists. ${ }^{51}$

50 Kawamura Hideya, 'Orokko, Giriyāku no Seikatsu to Fuyū', Karafuto Chōhō 6 (October 1937): pp. 155-65, quotation from p. 157.

51 Kitagawa, “'Otasu” no kurashi', pp. 15-18, reference from p. 15. 
Kawamura's own position, however, was also a profoundly problematic one. His official role was to 'modernise' and 'Japanise' his students by inculcating in them 'sentiments of nationality' and 'a spirit of diligent labour', and yet (like others in similar colonial roles) he clearly valued the indigenous languages and ways of life his school was seeking to eradicate, and tried to record them even as his school undermined their survival. The ambivalence of his position in the paradoxical landscape of Otasu were (as we shall see) to end both in disaster for many of his pupils and in a personal sense of defeat for Kawamura himself.

\section{Pathways Through Colonial Modernity}

The accounts left by former indigenous inhabitants of Otasu themselves tell yet another story. For them, the relatively loose and flexible links that had long connected them to other societies were now replaced by a much more intense and forcible process of exposure to the 'Japanese modern', creating a perilous landscape though which they had to pick their way as best they could. Often, this involved processes of hybridisation, through which new colonial experiences were married with older traditions in ways that made them comprehensible and usable.

A particularly vivid illustration of the way in which unfamiliar knowledge and experience could be reinterpreted in the framework of more familiar ways of knowing comes from some of the indigenous legends ethnographer Yamamoto Sukehiro collected in Otasu in the colonial era. The following legend, for example, told to him by a local Nivkh storyteller, is full of haunting suggestions of local responses to the arrival of the imported diseases that had ravaged the indigenous communities of Sakhalin/ Karafuto in the late nineteenth and early twentieth centuries:

Rōhen of the Kïrin (Evenk) people was watching over his reindeer on the banks of the Mui River, and then he went to set traps for rabbits beyond the Poronai River. But, sitting on the bank of the river, there was a Russian woman smoking a cigarette. When Rōhen approached her, she stood up and asked 'I am trying to go south towards the coast; which way should I go?' Rōhen replied, 'from here, the river is winding, and the journey is long. You had better cut straight across the tundra.' Rōhen had understood that this woman was the spirit of influenza, and so he told her to go across the tundra where no-one lived. The woman walked a little 
way ahead, passed two or three trees, and disappeared into the shadows of the forest. After he had seen this, a tornado arose, and whirled all the way to Taraika on the coast. ${ }^{52}$

From internal evidence, this story would seem to have originated in the early years of the twentieth century, and may perhaps refer to the particularly severe 1905 influenza epidemic that caused many deaths in Sakhalin indigenous communities. ${ }^{53}$ By the 1930 , the pressures of colonial assimilation had become much more intense, and the challenges faced by a younger generation are well illustrated by the stories of two members of the Daaxinneeni clan, ${ }^{54}$ one of six Uilta clans living in Japanese-ruled Karafuto. The Daaxinneeni clan had migrated in earlier times from the north-eastern coastal area of Sakhalin Island to the shores of Lake Taraika (now known as Lake Nevskoye) in the south, and then a number of the clan members had moved to Nokoro (now known as Vladmirovo). ${ }^{55}$ Among them were Gergulu, who had been born sometime in the 1890s, and was known for his shamanic powers. When the 'native village' of Otasu was created, Gergulu, his wife Anna and their children were moved into the village. ${ }^{56}$ The residents of Otasu continued to consult shamans (both male and female) about health problems and other problems, and Gergulu's position in the village, both as a shaman and a skilled hunter, was an important one. He was a major source of information for visiting ethnographers like Ishida Eiichirō. ${ }^{57}$

During the 1930s, Gergulu and Anna, who had two daughters but no son, adopted a boy named Geeldanu, ${ }^{58}$ who was then aged about five or six, and was also a member of the Daaxinneeni clan. ${ }^{59}$ Adoption was quite common amongst the indigenous people of the Okhotsk region, and Geeldanu maintained close contact with his birth mother, who lived just across the road from his adoptive parents: since she was blind, she summoned him to help with daily tasks around the house. Geeldanu grew up in Otasu, attending the village school along with other members of his

52 Yamamoto Sukehiro. 'Giriyaku, Yakūto no Minwa', Minzokugaku Kenkyū 27, no. 3 (1963): p. 573.

53 See, for example, Piłsudski, 'B. O. Pilsudski's Report', p. 215; Bronislaw Piłsudski, 'Selected Information on Individual Ainu Settlements on the Island of Sakhalin', in The Collected Works of Bronislaw Pitsudski, pp. 311-30, particularly p. 311, doi.org/10.1515/9783110820768-018.

54 The transliteration of the Uilta language is complex, because the sounds do not correspond precisely with those of European languages or of Japanese. Here I use the romanisation followed by the linguist and scholar of the Uilta language Ikegami Jirō.

55 Ishida, 'Hōryō Minami Karafuto', p. 355.

56 Tanaka and Gendānu, Gendānu, p. 26.

57 Ishida, 'Hōryō Minami Karafuto', p. 335.

58 Sometimes transcribed via Japanese as 'Gendānu'.

59 Tanaka and Gendānu, Gendānu, pp. 26-31. 
double family. There they received an intensive program of 'Japanisation', which included being given Japanese names - Daaxinneeni Geeldanu became 'Kitagawa Gentarō' - learning the Japanese language and Japanese patriotic songs, and being taught the art of growing vegetables and buckwheat (relatively unfamiliar foods as the Uilta diet had consisted mostly of meat and fish supplemented with wild plant food such as furep) ${ }^{60}$

Like many of his schoolmates, Geeldanu generally began his day by going fishing in the river for trout that was sold to customers who crossed over to the village from the nearby town of Shisuka. The pocket money he earned from these and other tasks was spent on trips to Shisuka to see samurai movies at the local cinema, followed by a meal of fried udon on the way home, or on visits to the town's summer festival, where you could buy ice cream. The visits to Shisuka were a source of both delight and pain. The town, with its shops and restaurants, trucks and motorcars, and the smokestacks of the Öji paper mill sending their plumes billowing over its outskirts, was exotic and exciting, but also a place of painful encounters with the sharp end of colonialism. Within the Otasu school (as Geeldanu's adoptive sister recalled) 'we didn't even know that discrimination existed', but when the children and their parents went to town, they would sometimes face mockery and insults from the local Japanese residents. ${ }^{61}$

The desire to escape from the pain of discrimination was, perhaps, one of the powerful forces that made Geeldanu and other children internalise the messages conveyed by their school education, longing to 'become Japanese'. ${ }^{62}$ For Geeldanu, serious education in Uilta hunting techniques came only after he had completed six years of school, when his adoptive father Gergulu took him to the coast to learn the techniques of shooting seals on the floating ice shoals, and of shaping the handmade bullets used in the Murata rifles that most Uilta then used for hunting. Bullets were often made by cutting up strips of lead and placing the pieces in a bottle, which was given to children to use as a rattle; after a few months of use, the constant shaking and friction would turn the lead into beautifully smooth and rounded bullets. ${ }^{63}$ Geeldanu's main employment after graduation, though, was not in hunting and reindeer herding, but in

60 Tanaka and Gendānu, Gendānu, pp. 32-34; Kitagawa, "'Otasu” no kurashi', p. 16.

61 Kitagawa Aiko, Watashi no Oitachi (Abashiri: Jakka Dukhuni, 2001), pp. 7-8.

62 Tanaka and Gendānu, Gendānu, pp. 33-35.

63 Kitagawa Aiko (address to seminar 'Saharin Shōsū Minzoku no Kako to Genzai' ['The Ethnic Minorities of Sakhalin: Past and Present'], Hokkaido Museum of Northern Peoples, Abashiri, 20-21 September 1997). 
a job with Shisuka city administration, who employed him as a ferry-boat ticket collector and as a clerk before promoting him to captain the ferry between Shisuka and Otasu. ${ }^{64}$

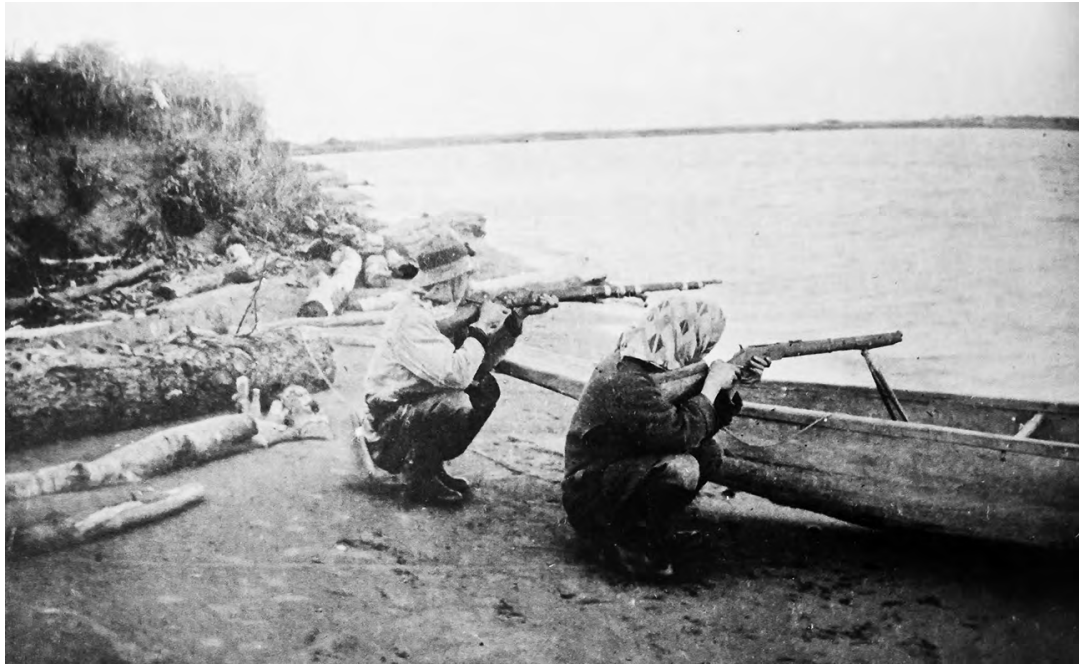

Figure 7.6. Indigenous people hunting marine mammals near Otasu.

Source: Karafuto Chō, ed., Karafuto Shashinchō (Toyohara: 1929).

Geeldanu's adoptive sister, who was given the Japanese name Kitagawa Aiko, also attended the village school, and took part enthusiastically in the headmaster's schemes to encourage the production of embroidered items for sale to Japanese tourists. She learnt the skills of Uilta embroidery, not from her own mother but from the mother of a schoolfriend - a woman who was known for her particularly fine sewing. ${ }^{65}$ Uilta embroidery is both distinctive and symbolic of the long history of trade and interaction amongst the many communities of the Okhotsk and Lower Amur. Its designs bear a strong resemblance to those found in Nivkh, Ul'chi, Nanai and other neighbouring societies, though Uilta designs have a particularly strong tendency to symmetry, and demanded very delicate stitching of reindeer hides to ensure that the design was visible only on one side. ${ }^{66}$ The development of these embroidery skills had long relied on commercial relationships with neighbouring societies that could provide access to

64 Tanaka and Gendānu, Gendānu, pp. 63-70.

65 Kitagawa, “'Otasu” no kurashi', pp. 15-16.

66 Hokkaidō Kyōiku Iinkai, Uiruta Minyō Bunkazai Kinkyū Chōsa Hōkokusho, no. 10 (Sapporo: Hokkaidō Kyōiku Iinkai, 1989), pp. 84-101. 
steel sewing needles. The traveller Charles Hawes, who visited a Uilta community at Chaivo on the east coast of Sakhalin at the beginning of the twentieth century, described how metal needles were treasured, carefully stored in special needle cases made of ornamentally carved bone, and passed down from one generation to the next as heirlooms. ${ }^{67}$

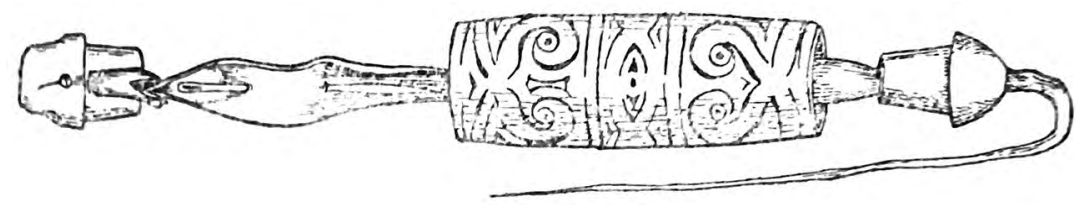

Figure 7.7. Uilta needle case, early twentieth century.

Source: Charles H Hawes, In the Uttermost East (London and New York: Harper and Brothers, 1903).

The stories told by Otasu residents like Daaxinneeni Geeldanu and Kitagawa Aiko give some sense of the complex world through which young indigenous residents of Karafuto sought a path in the 1920s and 1930s - rapidly absorbing newly imported elements of Japanese culture while also learning older Uilta skills and knowledge from their elders, and often finding creative ways to combine the two. Thus the Murata rifle could fit conveniently into, and enhance, Uilta hunting skills, and Uilta embroidery could be applied to the creation of tourist souvenirs.

\section{The Martial Arts Hall}

But on the border, culture was never really separable from politics. In August 1942, museum director Yamamoto Sukehiro composed an introduction to his account of the traditional lifestyles of the 'primitive peoples of Karafuto' in which he wrote:

These are people whose ancestors or fathers migrated to Karafuto at some point in the past; sometimes they fought with blizzards and sometimes they struggled with ice-floes, and they spent many generations in wild areas which are not blessed with natural wealth; today they live by the waters of the Poronai River, having created their home in the icy tundra of our Karafuto and made the snowfields their garden. Now they have been blessed by the

67 Charles H Hawes, In the Uttermost East (London and New York: Harper and Brothers, 1903), p. 221. 
beneficence of the Emperor, and their original primitive life is disappearing. However, their life with the reindeers in the depth of the tundra still continues to survive, and their everyday existence hunting sea mammals on the ice floes still appears unchanged. ${ }^{68}$

In the very month when Yamamoto wrote these words, every indigenous young man in Otasu received an official conscription notice from the Japanese military secret service requiring him to report to the village's martial arts hall on a certain morning. On the appointed day, about 30 Uilta, Nivkh and other young men gathered in front of the hall, where they were told that they would now become imperial Japanese soldiers. Many of the young men apparently welcomed conscription as a sign that they had finally been fully accepted as subjects of the Japanese emperor, and as an opportunity to disprove the demeaning stereotypes of inferiority and backwardness that had so often been applied to them by the colonisers. They were given medical inspections, and those who were passed as fit were provided with uniforms and ordered to move to the martial arts hall for intensive training. The recruitment of colonial subjects, who were not covered by Japan's wartime conscription laws, was in part apparently a response to reports that the Soviet Union was using indigenous people for spying missions on the island. ${ }^{69}$

The young Uilta woman Kitagawa Aiko, who was by then in her late teens, recalled:

In Otasu there was a thing called the youth martial arts hall. It was a residential camp, and its purpose was to gather together the young men of Otasu and train them as spies. After I graduated from school, I and a Nivkh girl called Matsuko went to work there, serving food. As I'd just finished school, I didn't really know how to do catering properly, but any way, there was this kind of atmosphere where we felt we should cooperate to do our bit for Japan. Not only we two but a lot of others applied for the job, but in the end they just took us ... Senior people from military intelligence [Tokumu Kikan] kept coming to stay the in hall. It wasn't just a place where the young men stayed, you see, so we had to make separate meals for those people and the young men. I used to get up at three in the morning and boil rice. Then, at the same time as serving breakfast, we had to fill the mess tins with

68 Yamamoto, Karafuto Genshi Minzoku, p. 1.

69 Tanaka and Gendānu, Gendānu, pp. 92-94; Hokkaidō Dōritsu Hoppō Minzoku Hakubutsukan, Karafuto 1905-45, pp. 12-13. 
packed lunches. In the evening when the young men came back there would be a mountain of empty mess tins to clear up, as well as dinner to be sorted out. I used to get back home after $11 \mathrm{pm}^{70}$

Kitagawa's adoptive brother, Daaxinneeni Geeldanu was one of those who had passed the medical and was being trained for the spy missions. After their initial training, these young men were sworn to secrecy and allowed to return to 'civilian' life for a while, but then intermittently summonsed to be sent on missions to the border area, where their intimate knowledge of the forest landscape was put to use in tasks such as observing the movements of border guards and conducting surveillance in case of possible infiltration from the Russian side. ${ }^{71}$ After Japan's defeat in August 1945, the Soviet army swept into Sakhalin and the Japanese population of Shishuka and surrounding areas crowded the railway station and roads, fleeing southwards in the direction of Japan. Many of the indigenous people of Otasu attempted to join them, but before they could find transport to take them southwards, the Soviet forces arrived and promptly arrested the young men who had been trained for spying missions by the Japanese. Daaxinneeni Geeldanu and his comrades-in-arms were sent to a military court in the city of Toyohara (now Yuzhno-Sakhalinsk) for trial as 'war criminals', found guilty and transported to labour camps near Krasnoyarsk in Siberia. Other indigenous people from Karafuto were also sent to labour camps for 'espionage', and many of them died in the harsh conditions of the Siberian camps - among them Kitagawa Aiko's Evenk husband, whom she had married just six months before his arrest. ${ }^{72}$ Kitagawa herself was also held for questioning by the Soviet authorities for about three months; she was released and went to work in a factory on Shisuka (by then renamed Poronaisk).

Meanwhile, the Saha 'village head' Dmitri Vinokurov, who had probably been engaged in intelligence gathering for both sides many years, had finally come under suspicion from the Japanese authorities in 1938 and been arrested and imprisoned in Toyohara for two years. He was released in 1940, but died in Otasu two years later of health problems contracted while in prison, having in his final year of life abandoned his dream of

70 Kitagawa, ““Otasu” no kurashi', p. 17.

71 Tanaka and Gendānu, Gendānu, pp. 95-128.

72 Kitagawa, Watashi no Oitachi, p. 11. 
an independent Yakut Republic. ${ }^{73}$ After Japan's defeat, the few remaining inhabitants of Otasu moved out of the village, and the 'capital city of the natives' disappeared from the map.

While almost all the Japanese inhabitants of Karafuto were repatriated to Japan after the war, the fate of the island's indigenous groups was more complex. Karafuto Ainu, who were regarded as Japanese nationals, were 'repatriated' to Hokkaido - a place where most had never lived. Many of them were resettled in coastal areas of northern Hokkaido, in villages like Wakasakanai in the north-west and Tokoro near Abashiri, whose harsh environment made them relatively unattractive to majority Japanese. ${ }^{74}$ Meanwhile Uilta, Nivkh and other small indigenous groups had never been given full Japanese nationality and (together with the thousands of Koreans who had been brought to the colony to work in coal mines and construction projects) were left in a postwar limbo. It was not until the 1950 s that some survivors of the disaster that had befallen the community of Otasu were allowed to migrate to Japan, where most settled around the city of Abashiri on the north coast of Hokkaido. Among them were Daaxinneeni Geeldanu, who arrived in Japan in April 1955 after being released from a Siberian labour camp, ${ }^{75}$ as well as his adoptive parents Gergulu and Anna, and his sister Kitagawa Aiko, who had remarried, her second husband being a Korean man who been brought to Karafuto as forced labourer in the coal mines. ${ }^{76}$

As for the school teacher Kawamura Hideya, who had spent the past 15 years teaching the children of Otasu how to become good imperial subjects, in his final encounters with his students before his own repatriation in 1947, he wept and asked their forgiveness for his part in the colonial system. During his time in Otasu he had amassed a mountain of notebooks filled with his 18 years of careful observations of life in Otasu, but most of these were abandoned during his return to Japan. Kitagawa Aiko recalled how she met Kawamura shortly before he was repatriated from Karafuto to Japan.

73 Vishinevskii, Otasu.

74 See Inoue, 'Case Study on Identity Issues'; also Emiko Ohnuki-Tierney, Illness and Healing Amongst the Sakhalin Ainu: A Symbolic Interpretation (Cambridge and London: Cambridge University Press, 1981).

75 See Ikegami Jirō, Giryaku, Orokko Kibutsu Kaisetsusho: Kitagawa Gentarō Hitsuroku 'Uilta no Kotoba’ 1 (Abashiri: Abashiri Hoppō Minzoku Bunka Hozon Kyōkai, 1986).

76 Kitagawa, Watashi no Oitachi, pp. 16-18. 
He apologised to me and said 'what I taught you was wrong'. Then he said, 'from now on, you can do things the way you think right.' I thought, 'OK, I can do that. But in that case I am not going back to being Uilta, nor am I going to become Japanese'. That was what I decided at that time. ${ }^{7}$

\section{Off the Map}

The architecture of Otasu was filled with colonial paradoxes. The functional modernity of new 'barrack' housing, the school and the martial arts hall shared space with the 'exotic' forms of reindeer herders' tents and the sacred symbols of the indigenous graveyard. Visitors to the village could choose their perspective, avoiding its unsettling ambivalence by focusing on one aspect or the other. But the indigenous people who lived in Otasu did not have that luxury. They were required to live lives that constantly moved between the uneasy juxtapositions of the 'representative native village'. The theories of modernity and development prescribed a oneway journey: from 'indigenous' to 'national', and from 'traditional' to 'modern'. But in practice, life for the villagers of Otasu did not flow in this simple one-way direction. Instead, each day they found it necessary to negotiate a path that crossed back and forth across these boundaries. Neither Japanese nor indigenous society offered much in the way of mental maps to help them on this journey, and there can be no doubt that many found it a painful and disorienting journey.

One remarkable expression of that journey is a tiny book - a miniature autobiography - written by Kitagawa Aiko in the early 1980 s. $^{78}$ The book is handwritten, and illustrated with beautiful drawings of the traditional Uilta designs that Kitagawa and her brother Geeldanu were to spend much of the later part of their lives seeking to preserve (see Chapter 8). But the text that accompanies these drawings is not an account of 'Uilta tradition', but rather a vivid account of Kitagawa's determination to be 'neither Uilta nor Japanese'. It is a stark personal story of a life lived first in Otasu, and then the town of Poronaisk, where social isolation and grim economic conditions left her struggling with thoughts of suicide. Although she and other family members chose to migrate to Japan in the late 1950s, seeing this as the best option open to them, they found themselves confronting

77 Kitagawa, “'Otasu” no kurashi', p. 18.

78 Kitagawa, Watashi no Oitachi. 
ongoing struggles with prejudice and dislocation: struggles that also profoundly affected the lives of the next generation. ${ }^{79}$ The story has no simple end. The harsh story of Kitagawa's life and the charming drawings with which she illustrated it are in irreconcilable tension with one another. The design and structure of Otasu had the power to tear societies apart, and more than half a century after the village and colony Karafuto itself disappeared, the rifts it engendered have yet to be fully healed.

79 Kitagawa, Watashi no Oitachi; see also Ikegami, Giryaku, Orokko. 
This text is taken from On the Frontiers of History: Rethinking East Asian Borders, by Tessa Morris-Suzuki, published 2020 by ANU Press, The Australian National University, Canberra, Australia.

doi.org/10.22459/OFH.2020.07 